\title{
Pemantauan, Proteksi, dan Ekualisasi Baterai Lithium-ion Tersusun Seri Menggunakan Konverter Buck-Boost dan LC Seri dengan Kontrol Synchronous Phase Shift
}

\author{
Diaz Ficry Arfianto, Dimas Anton Asfani, dan Daniar Fahmi. \\ Jurusan Teknik Elektro, Fakultas Teknologi Industri, Institut Teknologi Sepuluh Nopember (ITS) \\ Jl. Arief Rahman Hakim, Surabaya 60111 \\ E-mail:,diaz12@mhs.ee.its.ac.id, anton@ee.its.ac.id,daniar.fahmi@ee.its.ac.id
}

\begin{abstract}
Abstrak --- Baterai jenis lithium-ion kini dipilih sebagai penyimpan energi pada kendaraan lsitrik dikarenakan power density dan energy density yang lebih besar dibandingkan baterai jenis lain. Namun, baterai lithium ion memiliki kekurangan yakni sangat sensitif terhadap overcharge. Selain itu, masalah ketidakseimbangan kapasitas baterai tersusun seri dapat mempengaruhi performa baterai secara keseluruhan. Dalam tugas akhir ini diimplementasikan skala laboratorium sistem pemantauan dan proteksi pada empat sel baterai lithiumion tersusun seri agar baterai lebih aman dari overvoltage, undervoltage dan overheat . Selain itu ekualisasi untuk menyeimbangkan kapasistas baterai sehingga masa hidup dan kapasitas baterai dapat diperpanjang. Hasil pengujian skala laboratorium menunjukan pemantauan tegangan mendapat error terbesar $1,25 \%$ dan pemantauan suhu mencapai error terbesar $4,97 \%$. Sistem proteksi baterai dapat bekerja memutus koneksi baterai sehingga menjadi sirkuit terbuka jika mendeteksi overvoltage, undervoltage, dan overheat. Serta ekualisasi 4 baterai lithium tersusun seri dapat dialkukan dengan waktu tempuh $\mathbf{4 8}$ menit.
\end{abstract}

Kata kunci- Baterai Lithium-ion, Pemantauan dan Proteksi Baterai, Ekualisasi, Konverter Buck-Bosot dan $L C$ seri.

\section{Pendahuluan}

B TERAI merupakan penyimpan energi yang sangat penting bagi prasyarat kendaraan listrik saat ini. Tanpa adanya baterai, kendaraan listrik tidak akan bisa melaju sebagaimana mestinya. Baterai berbasis Lithium memiliki banyak kelebihan dibanding baterai konvensional seperti Nickel-Cadmium, Nickel-Metalhydrate ataupun Lead Acid [1]. Kelebihan baterai berbasis Lithium adalah densiti energi yang tinggi, densiti daya yang tinggi, self-discharge yang rendah, fast charging, rasio massa-keenergy yang tinggi, tidak ada memory effect, tahan lama jika proses chraging sesuai [2]. Namun, baterai berbasis Lithium juga memiliki kekurangan kurang toleran, sehingga memerlukan pemantauan dan prosesur proteksi yang akurat untuk memastikan tidak overcharge pada salah satu sel baterai serta memastikan baterai tidak overheat yang dapat mengurangi umur baterai.
Perlunya baterai sebagai sumber energi pada sumber listrik menitikberatkan pada keandalan baterai dan keamanan dalam penggunaanya. Baterai Lithium dalam bentuk pack memungkinkan memiliki perbedaan karakteristik pada setiap sel di dalamnya baik dalam karakteristik kimia maupun kelistrikannya [3]. Ketidaksamaan ini dapat menyebabkan baterai panas dengan keadaan terparahnya terbakar yang membuat ekualisasi baterai menjadi tidak terdispensasi untuk menjaga baterai dan memanjangkan umur baterai [3]. Metode yang digunakan pada proses ekualisasi pun bermacam-macam, proses ekualisasi harus efisien dan juga mudah diaplikasikan serta mempunyai keandalan yang tinggi. Metode yang sesuai dengan kriteria tersebut salah satunya adalah buck-boost LC seri converter [4].

Pada tugas akhir ini direncanakan proses ekualisasi menggunakan metode buck-boost LC seri converter dengan phase shift controller yang memiliki kemampuan lebih baik dari metode lainya (efisiensi, kecepatan pengisian, kemudahan membuat) [5,6]. Proses ekualisasi ini direncankan secara otomatis bergabung dengan sistem pemantauan dan proteksi melanjutkan dari tugas akhir yang sudah dikerjakan sebelumnya. Selain itu, proses pemantauan tegangan dan suhu serta proteksi baterai terhadap overcharge, overdischarge, dan overheat $[2,4]$ juga akan diimplementasikan demi menjadi kondisi baterai tetap baik sehingga tetap aman dan berumur panjang.

\section{KARAKTERISTIK BATERAI LITHIUM-ION}

\section{A. Baterai Lithium-ion}

Baterai Lithium-ion merupakan salah satu jenis baterai yang banyak digunakan pada kendaraan listrik maupun perangkai elektronik dimasa kini. Elektrode aktif pada baterai Lithium-ion merupakan lithium metal oxide untuk elektrode positif sedangakan carbon pada elektrode negatif. Material ini menganut arus kolektor logam dengan bahan pengikat, biasanya berupa polivinilidena flourida (PVDF) atau kopolimer polivinilidena fluorida-hexafluoropropylene (PVDF-HFP), dan penencer kondukif. 


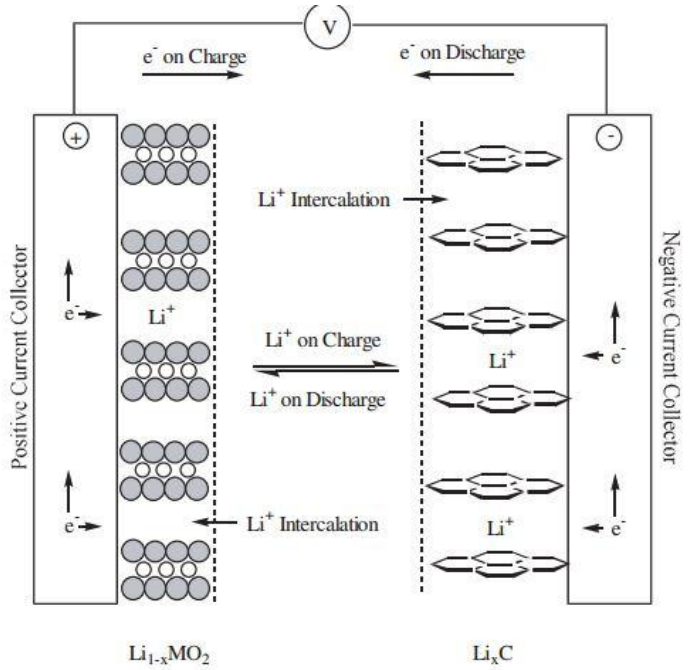

Gambar 1.Proses Electrochemical dalam Baterai Lithium-ion

\section{B. Perbandingan Baterai Lithium-ion dengan Jenis Lain}

Baterai lithium-ion memiliki kelebihan dibandingkan jenis lain yang dapat dilihat pada Tabel 1 berikut :

Tabel 1.

Perbandingan Baterai Lihtium-Ion dengan Jenis lain [1]

\begin{tabular}{|c|c|c|c|c|}
\hline Tipe Baterai & $\begin{array}{l}\text { Lead- } \\
\text { acid }\end{array}$ & $\mathrm{Ni}-\mathrm{Cd}$ & Ni-MH & Lithium-ion \\
\hline $\begin{array}{c}\text { Energy Density } \\
(W / k g)\end{array}$ & $30-50$ & $45-80$ & $60-120$ & $110-160$ \\
\hline Power Density & 180 & 150 & $250-1000$ & 1800 \\
\hline $\begin{array}{l}\text { Nominal } \\
\text { Voltage }\end{array}$ & $2 \mathrm{~V}$ & $1,25 \mathrm{~V}$ & $1,25 \mathrm{~V}$ & $3,6 \mathrm{~V}$ \\
\hline $\begin{array}{c}\text { Overcharge } \\
\text { Toleran }\end{array}$ & High & Moderate & Low & Very Low \\
\hline $\begin{array}{c}\text { Self-discharge } \\
\text { Operating }\end{array}$ & $\begin{array}{c}\text { Low } \\
-20-60\end{array}$ & $\begin{array}{l}\text { Moderate } \\
-40-60{ }^{\circ} \mathrm{C}\end{array}$ & $\begin{array}{c}\text { High } \\
-20-60\end{array}$ & $\begin{array}{l}\text { Very Low } \\
-20-60^{\circ} \mathrm{C}\end{array}$ \\
\hline Temperature & ${ }^{\circ} \mathrm{C}$ & & ${ }^{\circ} \mathrm{C}$ & \\
\hline Cycle Life & $200-300$ & 1500 & $300-500$ & $500-1000$ \\
\hline
\end{tabular}

\section{Sistem Manajemen baterai}

Pemantauan kondisi baterai merupakan hal penting dalam Baterai Manajemen Sistem (BMS). Pemantauan baterai digunakan untuk memeriksa dan mengontrol status baterai dalam kondisi aman saat sedang beroperasi. Beberapa fungsi dari BMS antara lain sebagai berikut :

1. Mampu untuk memprediksi level energi atau kapasitas baterai terpakai (SOC prediction capability). Dengan mengetahui SOC kita bisa menentukan kapan baterai harus di-charging, dan kapan harus berhenti mencharging. Dengan charging maupun discharging yang tepat maka baterai dapat berumur lebih lama karena reaksi kimiawi yang tidak dapat balik bisa dihindari.

2. Mampu untuk memutus dan menyambung baterai dari beban dan dari charger jika terjadi gangguan secara otomatis. Jenis gangguan yang akan memicu pemutusan otomatis misalnya keadaan sudah terisi penuh (fully charged), keadaan sudah SOC hampir nol (almost fully discharged), terbeban lebih yang menyebabkan overcurrent atau overheated dan lain-lain.

3. Mampu untuk melakukan ekualisasi sehingga baterai memiliki tegangan yang sama dengan harapaan kapasitas pada baterai dapat sama.

\section{Metode Proteksi Baterai}

Perlindungan elektrik pada baterai terkait dengan over voltage, dan under voltage. Selain itu baterai lithum-ion rentan memanas seiringproses charge-discharge sehingga perlu ada proteksi terhadap overheat.

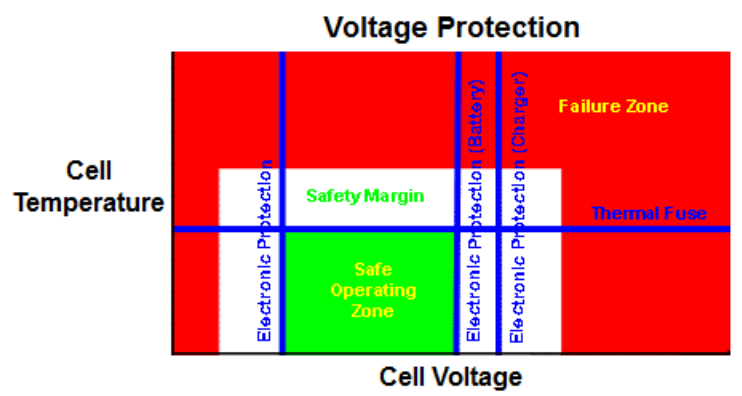

Gambar 2. Diagram proteksi tegangan dan suhu [7]

Pada gambar 2. menunjukkan skema untuk batas atas dan bawah tegangan, serta perlindungan suhu. Baterai dapat rusak baik oleh overvoltage yang dapat terjadi selama charging dan oleh undervoltage akibat discharge yang berlebihan, sehingga batas tegangan untuk kedua proses tersebut harus diperhatikan. Dengan menyediakan charger dengan masukan tegangan disertai sensor tegangan dan sensor suhu pada baterai, charger bisa dipotong ketika baterai mencapai batas kontrol yang telah ditentukan.

\section{PERANCANGAN PEMBUATAN SISTEM PEMANTAUAN, PROTEKSI DAN EKUALISASI}

Sistem keseluruhan terdiri dari tiga sub-sistem yakni pemantauan, proteksi, dan ekualisasi. Perancanagan sistem pemantauan meliputi pemantauan tegangan, estimasi state of charge, dan pemantauan suhu. Proteksi meliputi proteksi overvoltage, undervoltage, dan overheat. Terakhir sistem ekualisasi menggunakan konverter buck-boost dan LC seri dengan kontrol synchrnous phase shift.

Sistem bermula dengan memantau tegangan dan suhu sehingga didapat tegangan dan suhu tiap sel baterai. Kemudian sistem proteksi akan mengiterupsi jika ada tegangan atau suhu baterai yang melebihi toleransi. Setelah itu state of charge akan ditranslasi dari tegangan. Lalu jika membutuhkan ekualisasi maka ekualisasi akan berlangsung. Jika ingin melakukan proses charge \& discharge maka akan berlangsung. Jika tidak melakukan keduanya sistem aka mengulang kembali ke awal (idle). 


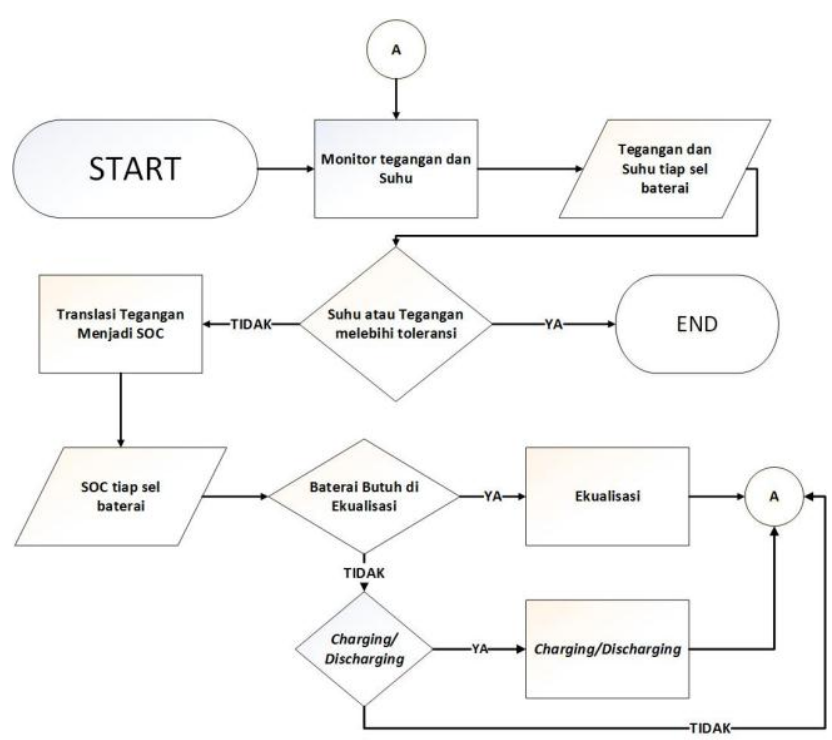

Gambar 3. Diagram blok perancangan sistem keseluruhan

\section{A. Sistem Pemantauan}

Pemantauan baterai lithium-ion tersusun seri memerlukan persangkat tambahan berupa battery IC monitoring yang dapat digunakan untuk memantau tegangan baterai pada tiap sel. Prinsip kerja IC ini sebenarnya merupakan multiplexer sehingga memantau tegangan bergantian. Pemantuan tegangan menggunakan IC BQ76925. Selain multiplexer, ICBQ76925 merupakan levelshifter sehingga keluaran IC perlu di kembali kan dengan persamaan berikut :

$$
V_{B}=V_{\text {out }} \text {.Gain }
$$

Sedangkan pemantaun suhu menggunakan sensor suhu LM35. Keluaran LM35 merupakan tegangan dengan skala 10 $\mathrm{mV} /{ }^{\circ} \mathrm{C}$ sehingga keluaran tegangan LM35 mengikuti persamaan berikut:

$$
T_{B}=\frac{\text { Vsensor }}{0,01}
$$

Terakhir pada sistem pemantauan ingin didapatkan state of scharge baterai Lithium-ion. Cara mendapatkan state of charge ini didapatkan dengan charge dan discharge test. Charge dan discharge test dilakukan untuk mendapatkan kurva sesuai datasheet seperti pada gambar 4 dan 5 .

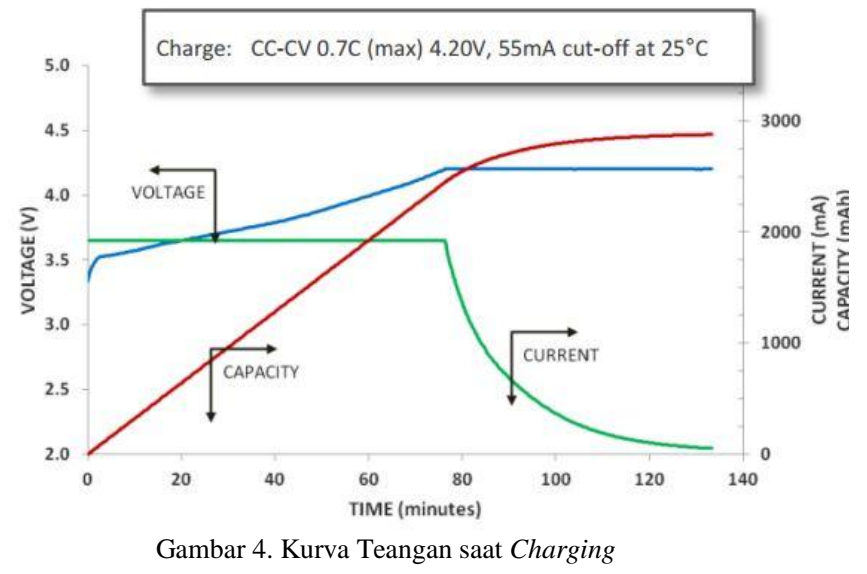

Gambar 4. Kurva Teangan saat Charging

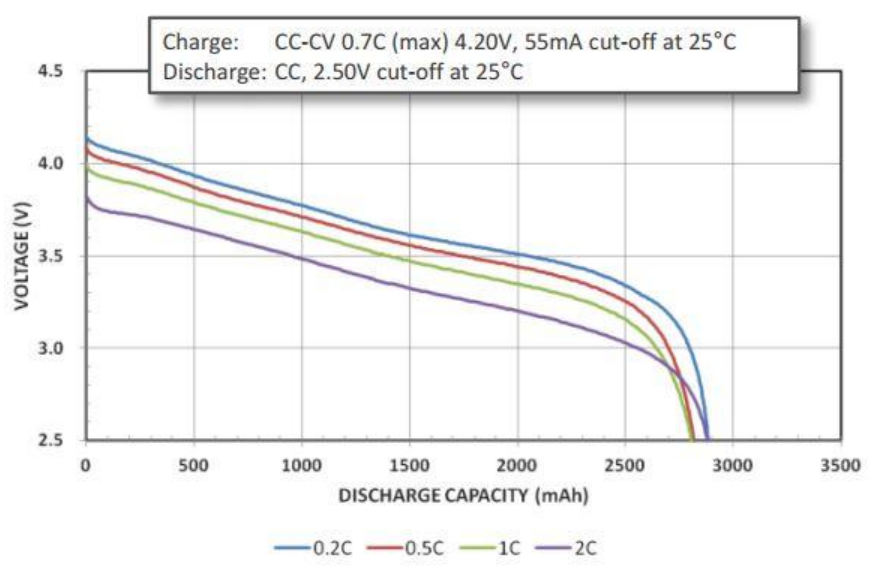

Gambar 5. Kurva Tegangan saat Discharging

\section{B. Sistem Proteksi}

Sistem proteksi dari baterai lithium-ion harus menjaga baterai agar tetap dalam kondisi stabil. Baterai lithium-ion harus terjaga dari overvoltage, undervoltage dan overheat.

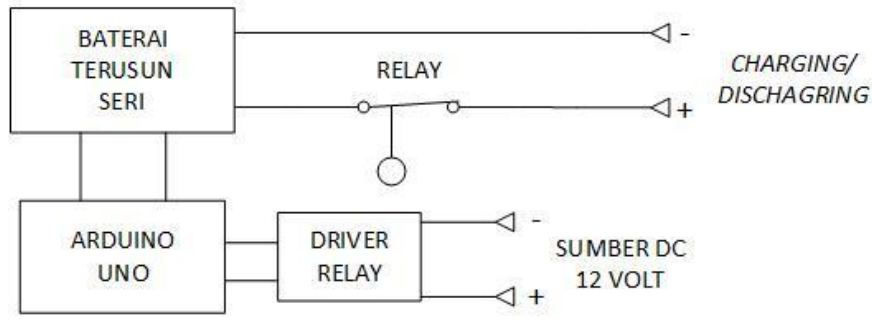

Gambar 6. Skema Proteksi Overvoltage dan Undervoltage

Gambar 6. Merupakan Proteksi Overvoltage dan undervoltage merupakan sistem kesatuan dengan dua batas yang berbeda. Proteksi overvoltage akan memutus rangkaian jika mendeteksi salah satu baterai menyentuh tegangan 4.1 volt sedangkan pada proteksi undervoltage akan memutus rangakain jika mendeteksi salah satu baterai menyentuh tegangan 2.8 Volt

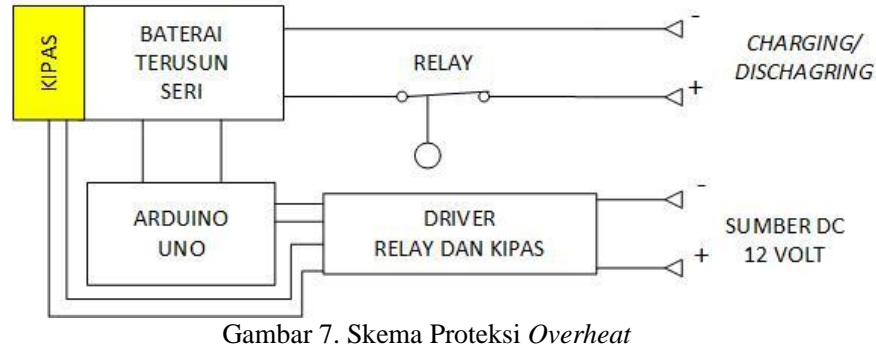

Gambar 7. merupakan skema proteksi overheat yang memiliki dua tahap. Tahap pertama adalah preventif dengan menyalakan kipas untuk mendinginkan baterai. Kipas akan nyala jika mendeteksi baterai mencapai suhu $35{ }^{\circ} \mathrm{C}$, sedangakan pemutusan relay akan dimulai jika baterai menyentuh suhu $45{ }^{\circ} \mathrm{C}$.

\section{Sistem Ekualisasi Menggunakan Konverter Buck-Boost dan LC seri dengan Kontrol Synchronous Phase Shift}

Sistem ekualisasi mengunakan empat sel baterai lithum ion sebagai objeknya. Adapaun rangakain ekualisasi sebagai berikut : 


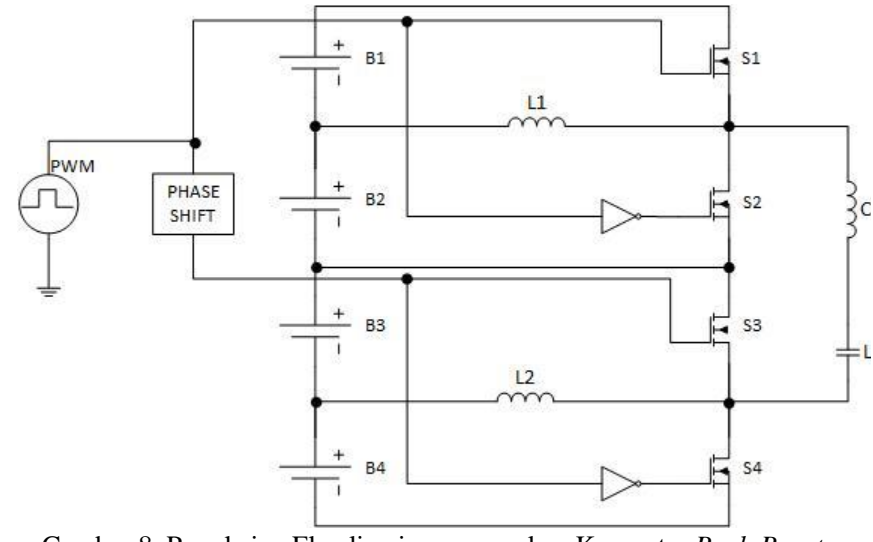

Gambar 8. Rangkaian Ekualisasi menggunakan Konverter Buck-Boost dan LC seri dengan Kontrol Synchronous Phase Shift.

Sistem ini menggunakan empat buah mosfet sebagai pensaklaranya yang menghubungkan baterai dengan rangakaian resonant (LC Seri). Perhitungan nilai kapasitor dan induktor seri dapat didapatkan dengan persamaan berikut :

$$
f_{r}=\frac{1}{2 . \pi \cdot \sqrt{L . C}}
$$

Sedangakan L1 dan L2 dapat disesuai dengan arus yang ingin dialirkan dengan persmaaan berikut :

$$
V_{\text {Baterai }}=L \cdot \frac{d i}{d t}=L \cdot \frac{\Delta i}{\Delta t}
$$

Proses ekualisasi menggunakan kontrol synchronous phase shift dimana dua dari empat saklar mengalami pergeseran waktu on. Ini dimaksudkan agar proses transfer pada rangakaian LC seri dapat terjadi sehingga arus akan lebih cepat ditransfer kepada baterai pada waktu berikutnya. Proses pensaklaran dijelaskan pada gambar 9.

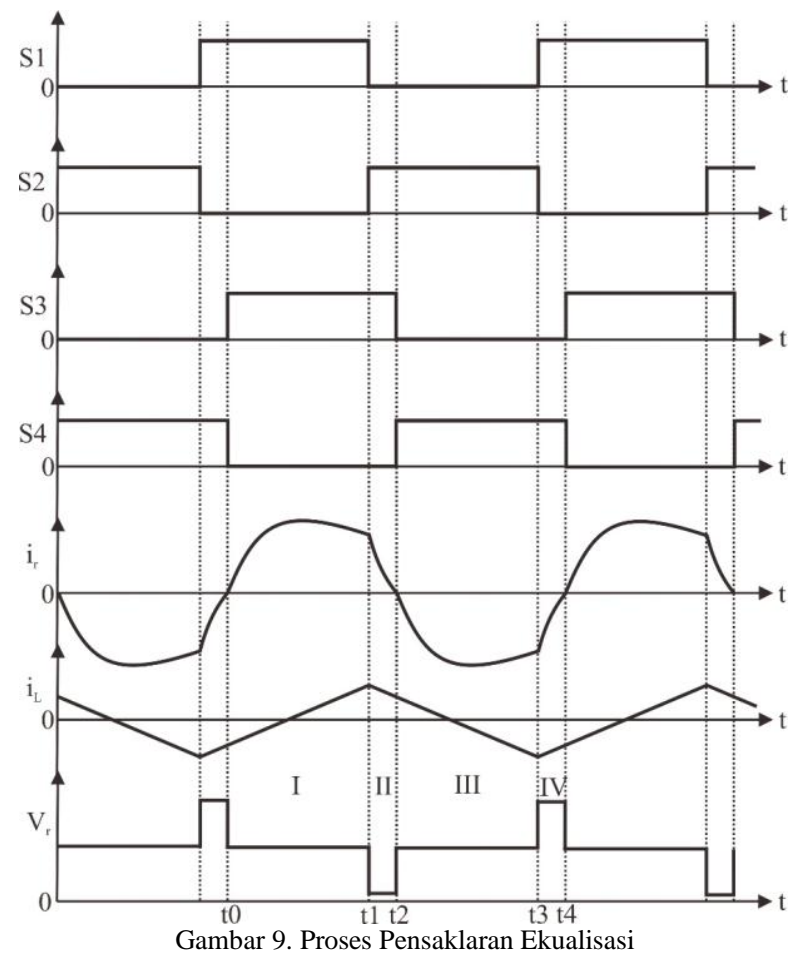

Proses pensaklaran dapat dijelaskan sebagai berikut.

1. Kondisi I, dimana induktor $\mathrm{Lr}$ dan kapasitor $\mathrm{Cr}$ terhubung dengan B1 dan B2. Oleh karena itu kapasitor $\mathrm{Cr}$ terisi muatan oleh B1 dan B2, dan arus $\mathrm{Lr}$ danCr (ir) meningkat dari nol. Pada kondisi ini energi ditransfer dari B1 dan B2 menuju Lr dan Cr. Dapat dilihat dari bentuk gelombangya seperti yang ditunjukakan pada dari periode t0 sampai $t 1$.

2. Kondisi II, dimana S2 dan S3 dalam kondisi on, sebalikanya S1 dan S4 off. Rangkaian induktor L dan kapasitor $\mathrm{Cr}$ terhubung singkat karena S2 dan S3 on. Kapasitor $\mathrm{Cr}$ akan terisi dari muatan yang berasal dari induktor Lr menyebabkan transfer energi dari induktor $\mathrm{Lr}$ dan $\mathrm{i}_{\mathrm{r}}$ akan berkruang mendekati nol.

3. Kondisi III, dimana S2 dan S4 dalam kondisi on, sebalikanya S1 dan S3 off. Induktor Lr dan kapasitor $\mathrm{Cr}$ terhubung dengan B3 dan B4. B3 dan B4 terisi muatan oleh kapasitor $\mathrm{Cr}$ sedangkan $\mathrm{i}_{\mathrm{r}}$ akan berkurang dari nol menjadi negatif. Oleh karena itu proses ini adalah transfer energi dari Lr dan Cr menuju B3 dan B4.

4. Kondisi IV, dimana S1 dan S4 dalam kondisi on, sebaliknya S2 dan S3 off. Oleh karena itu induktor Lr dan kapsitor $\mathrm{Cr}$ terhubung dengan keempat baterai yang terhubung seri. B1, B2, B3, dan B4 terisi muatan oleh induktor $\mathrm{Lr}$ dan kapasitor $\mathrm{Cr}$ serta $\mathrm{i}_{\mathrm{r}}$ meningkat menuju nol.

\section{ANALISIS PENGUJIAN SISTEM}

Analisis sistem terdiri dari pengujian pemantauan, proteksi dan ekualisasi pada baterai lithium ion tersusun seri sebanyak empat buah. Pengujian dilakukan pada tiap-tiap sub sistem.

\section{A. Analisis Data Pengujian Pemantauan}

Pengujian ini bertujuan untuk mengetahui error pada pemantauan tegangan dan suhu serta mengetahu estimasi state of charge.

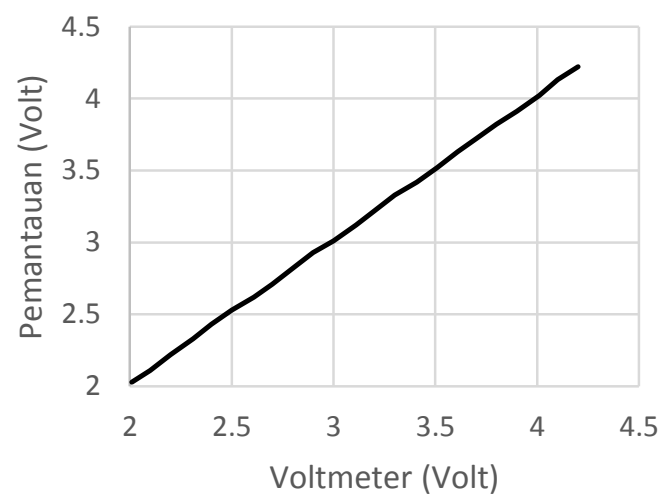

Gambar 10. Korelasi Pengukuran Voltmeter dan Pemantauan Tegangan

Gambar 10 menunjukan korelasi pengukuran dengan voltmeter dengan pemantauan tegangan oleh sistem. Pengukuran voltmeter menggunakan GW Instek GDM 8245 (akurasi: $\pm 0,003 \%+4$ ). Uji korelasi pearson pada pemantuan tegangan mencapai 0,9999 menunjukan korelasi yang kuat antara pengukuran voltmeter dengan peamantauan tegangan. 
Sedangakan error terbesar pada pengujian ini mencapai 1,25 $\%$.

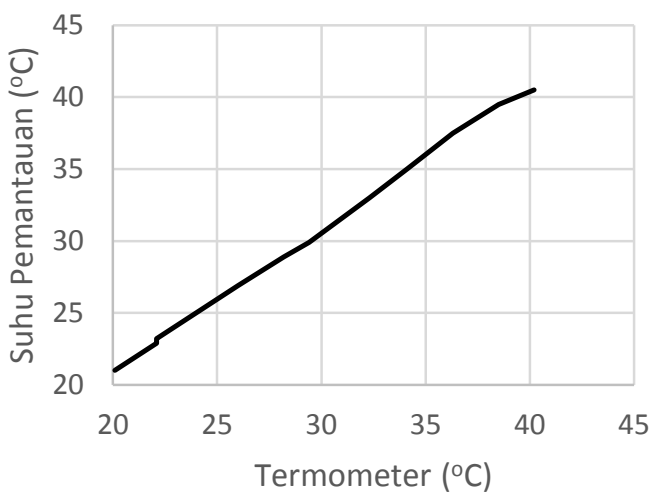

Gambar 11. Korelasi Pemantauan Suhu dengan Termometer dengan Pemantauan Suhu

Gambar 11 menunjukan korelasi pengukuran dengan termometer dengan pemantauan suhu pada sistem. Pengukuran suhu menggunakan termometer infrared KRISBOW KW06559 (akurasi : $\pm 1,5 \%)$ ). Uji korelasi pearson pada pemantuan tegangan mencapai 0,9993 menunjukan korelasi yang kuat antara pengukuran termometer dengan peamantauan suhu. Sedangakan error terbesar pada pengujian ini mencapai 4,97 $\%$.

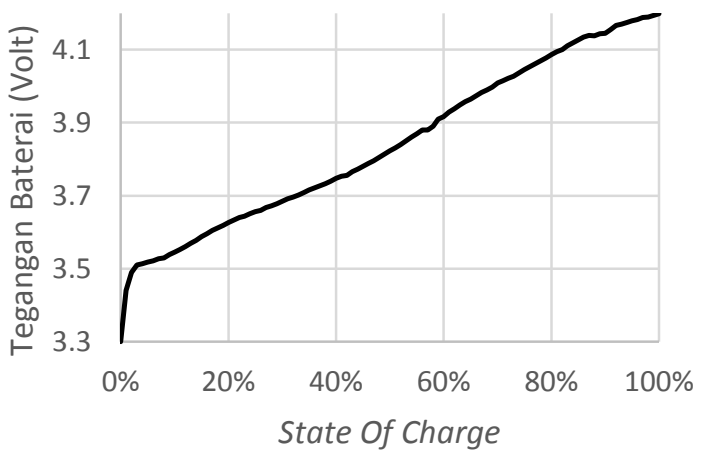

Gambar 12. Kurva State of Charge dengan Tegangan saat Charging

Gambar 12 merupakan kurva state of charge saat proses charging dimana charging menggunakan tegangan konstan 4,2 volt dan arus $1,45 \mathrm{~A}(0,5 \mathrm{C})$. Dapat dilihat pada kurva bahwa state of charge pada prores charging tidak linear terhadap kenaikan tegangan. Sedangakan gambar 13 merupakan kurva state of charge saat proses discharge dimana proses ini baterai didischarge dengan arus konstan 1,45 A $(0,5 \mathrm{C})$. Ini juga membuktikan bahwa state of charge pada proses discharging tidak linear terhadap penurunan tegangan.

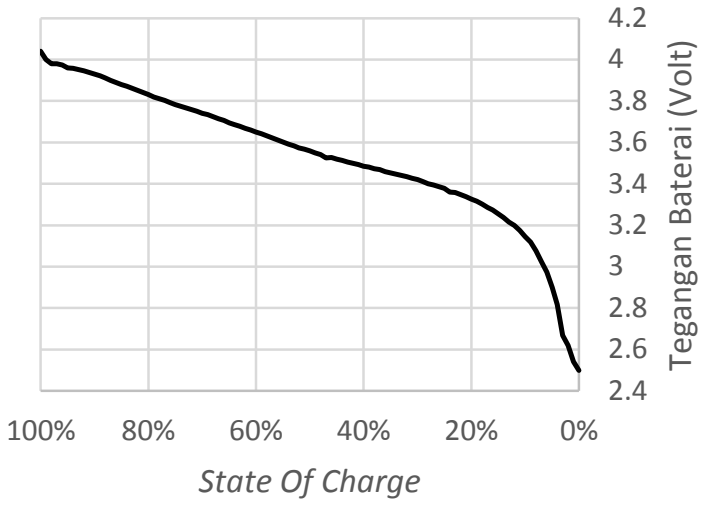

Gambar 13. Kurva State of Charge dengan Tegangan saat Discharging

\section{B. Analisis Data Pengujian Proteksi}

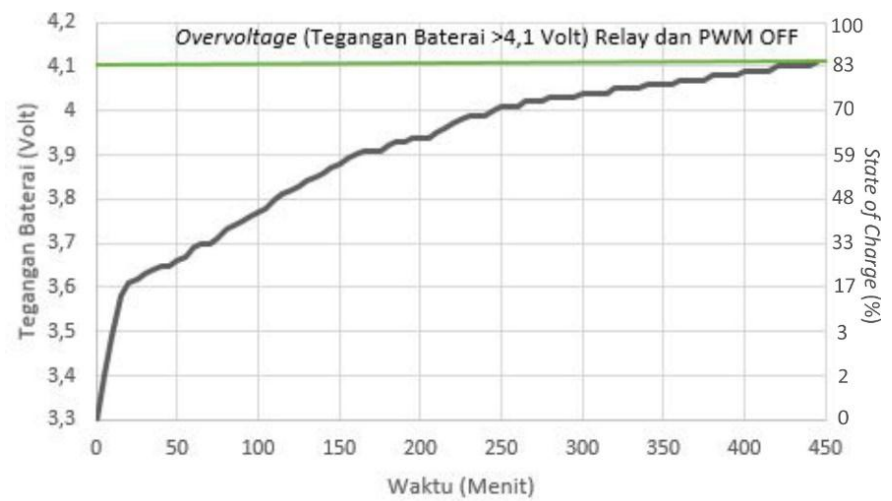

Gambar 14. Grafik Pengujian Overvoltage

Gambar 14 menunjukan proses proteksi adari overvoltage. Dari gambar dapat dilihat bahwa proteksi akan memutus rangkaian (PWM dan relay off) ketika tegangan emncapai 4,1 volt.

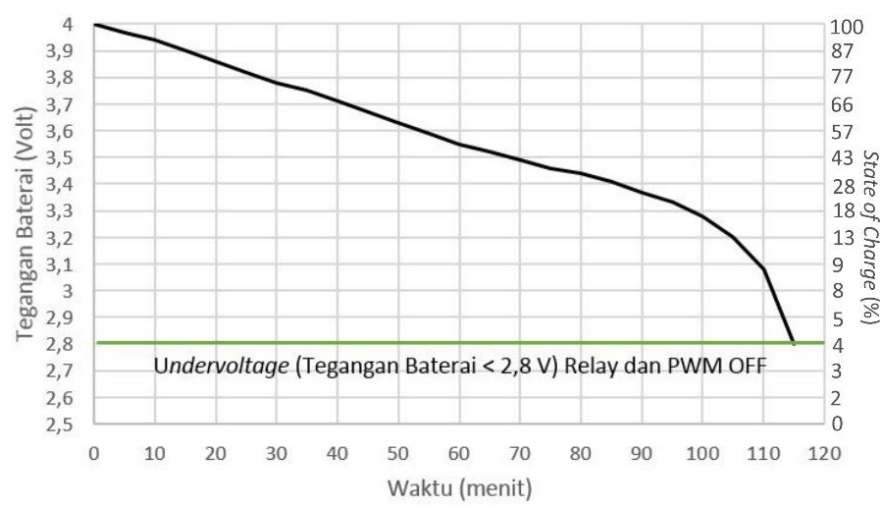

Gambar 15. Grafik Pengujian Undervoltage

Gambar 15 menunjukan proses proteksi dari undervoltage. Dari gambar dapat dilihat bahwa proteksi akan memutus rangkaian (PWM dan relay off) ketika tegangan mencapai 2,8 volt. 


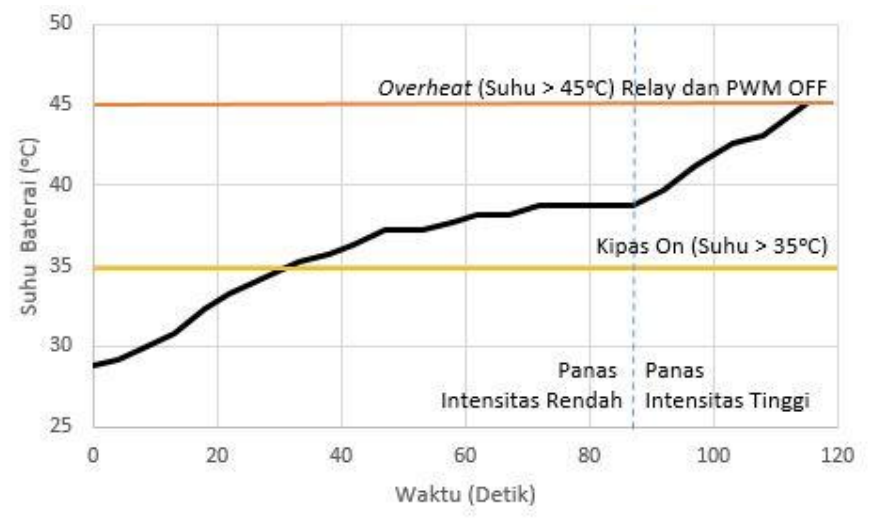

Gambar 16. Grafik Pengujian Overheat

Gambar 16 menunjukan proses proteksi overheat. Pada pengujian proteksi overheat digunakan dua intensitas yang berbeda pada sumber panas. Saat pengujian intensitas panas rendah suhu baterai mencapai $35^{\circ} \mathrm{C}$ sehingga kipas akan bekerja untu mendinginkan baterai. Dapat dilihat setelah bekerjanya kipas suhu akan cenderung konstan sehingga dapat melawan sumber panas. Selanjutnya instensitas panas akan ditinggikan sehingga kipas tidak mampu mengimbangi sehingga suhu baterai meningkat menyentuh $45{ }^{\circ} \mathrm{C}$ dimana relay dan PWM akan off menandakan rangkaian baterai telah terbuka.

\section{Analisis Data Pengujian Ekualisasi}
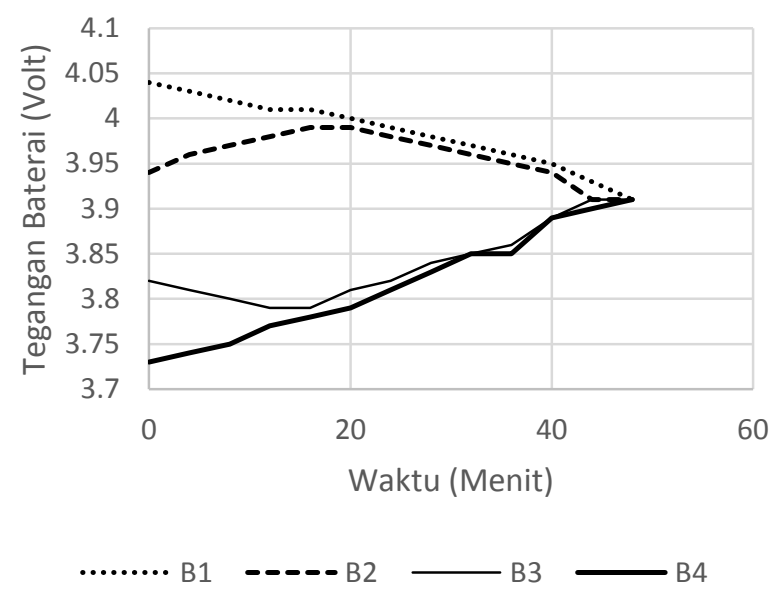

Gambar 17. Grafik Pengujian Ekualisasi

Pengujian ekualisasi adalah 4 buah baterai lithium-ion NCR18650PF terusun seri. Gambar 4.17. menunjukan waktu yang dibutuhkan untuk melakukan proses ekualisasi baterai adalah 48 menit. Walaupun terlihat ada anomali tegangnan yang disebabkan error pemantauan tegangan. Namun ini membuktikan bahwa sistem ekualisasi berkerja sesuai yang diharapakan setelah ditambahkan sistem pemantauan dan proteksi.

\section{KESIMPULAN}

Pemantauan tegangan baterai tersusun seri menggunakan IC BQ76925 dapat dilakukan sesuai dengan disesain dengan error tertinggi $1,25 \%$. Sedangkan, pemantauan suhu baterai dengan LM35 dapat dilakukan sesuai desain namun dengan error yang lebih tinggi menyentuh 4,97\% untuk error tertinggi. Translasi tegangan ke bentuk state of charge dapat dilakukan namun rentan mengalami error karena pembacan tegangan baterai yang masih memiliki error serta pengujian state of charge yang memiliki error.

Proteksi terhadap overvoltage dan undervoltage dapat dilakukan seketika pemantauan tegangan mendeteksi adanya tegangan baterai yang melebihi toleransi sehingga dapat memutus relay dan menonaktifkan PWM. Sedangkan, untuk proteksi terhadap overheat dapat dilakukan seketika pemantauan suhu mendeteksi adanya masalah suhu dengan proteksi preventif berupa proses pendinginan baterai ketika mencapai $35{ }^{\circ} \mathrm{C}$ dan pemutusan relay dan menonaktifkan PWM ketika mencapai $45{ }^{\circ} \mathrm{C}$. Terakhir, proses ekualisasi 4 buah baterai lithium-ion terusun seri dapat dilakukan dengan waktu tempuh 48 menit.

\section{DAFTAR PUSTAKA}

[1] Xiaopeng Chen, Weixiang Shen, Thanks Tu VO, Zhenwei Caoi, Ajay Kapoor. "An Overview of Lithium-ion Batteries for Eleectric Vehicles". International Power \& Energy Conference. December 2012.

[2] Amir Hossein Ranjbar. Anahita Banei. Amir Khoobroo. Babak Fahimi. "Online Estimation of State of Charge in Li-Ion Batteries Using Implse Respone Concept". IEEE Transactions on Smart Grid, Vol. 3, No. 1. March 2012

[3] Weigui Ji. Xi Lu. Yuan Ji. Yingbin Tang. Feng Ran. Fan Zheng Peng. "Low Cost Battery Equalizer Using Buck-Boost and Series LC Converter with Synchronous Phase-Shift Control".Applied Power Electronic Conference and Exposition (APEC). March 2013.

[4] Kim, Choll-Ho. Kim, Moon-Young. Moon, Gun-Woo. "A Modularized Charge Equalizer Using a Battery Monitoring IC for Series-Connected Li-Ion Battery Strings in Electric Vehicles". IEEE Transactions on Power Electronics, Vol. 28, No. 8. August 2013.

[5] Kyung-Min Lee. Yoo-Chae Chung. Chang-Hyeon Sung. Bongkoo Kang. "Active Cell Balancing of Li-Ion Batteries Using LC Series Resonant Circuit". IEEE Transactions on Industrial Electronics. Vol. 2, No. 9. September 2015.

[6] Priyana, Soni, "Ekualisasi Baterai Tersusun Seri Menggunakan Konverter Buck-Boost dan LC Seri dengean Synchronous Phase Shift Control", Jurusan Teknik Elektro, Institut Teknologi Sepuluh Nopember Surabaya, Surabaya, Juli, 2015

[7] Electropedia Admin, 2005. "Battery Protection Methods". http://www.mpoweruk.com/protection.htm, diakses 29 Mei 2016. 